\title{
ANTIMICROBIAL ACTIVITY OF SOME MARINE ALGAE OF SRI LANKA
}

\author{
B.M. RATNAYAKE BANDARA, A.A.L. GUNATILAKA, \\ N. SAVITRI KUMAR, W.R. WIMALASIRI- \\ Department of Chemistry, University of Peradeniya, Peradeniya, Sri Lanka.
}

AND

N.K.B. ADIKARAM, S. BALASUBRAMANIAM

Department of Botany, University of Peradeniya, Peradeniya, Sri Lanka.

(Date of receipt : 08 January 1988)

(Date of acceptance : 08 June "1988)

\begin{abstract}
Thirty five species of seaweeds were screened for antibacterial (against Stapbylococcus aureus and Escherichia coli) and antifungal (against Cladosporium cladosporioides and Candida albicans) activity. Twenty six species exhibited antibacterial and/or antifungal activity. Extracts with pronounced activity were obtained from Chondrococcus hornemanni (Rhodophyta) and the active component was found in a mixture containing dibalogenated monoterpenes. Acrylic acid appears to be responsible for the antimicrobial activity of Cracilaria corticata (Rhodophyta) and Ulva lactuca (Chlorophyta).
\end{abstract}

\section{Introduction}

Marine flora are known to contain biologically active substances including antimicrobial compounds. A variety of marine algae collected mostly from Caribbean and Pacific waters have been screened for antimicrobial activity. ${ }^{2,6}$

Marine algae have been found abundant particularly along the Northern and Southern coastal regions of Sri Lanka. The algal vegetation along the coasts shows distinct floristic associations and seasonal variations. In a floristic survey in 1961, the presence of 315 species of algae distributed among the orders Chlorophyta, Phaeophyta and Rhodophyta has been recorded from the coastal areas in Sri Lanka. ${ }^{7}$ Here we present the results of screening of 35 marine algae collected in Sri Lanka for their antimicrobial activity against Cladosporium cladosporioides, Candida albicans, Staphylococcus aureus and Escherichia coli and chemical fractionation of the extracts from Chondrococcus hornemanni, which was found to be the most active seaweed.

\section{Materials and Methods}

\subsection{Algal Specimens}

Algal specimens were collected from shallow waters of Mandativu, Mankum. ban, Keeramalai and Thiruvadinilayam in the Jaffna peninsula (Northern Coast) and also at Kirinda and Tangalla along the Southern Coast of Sri 
Lanka in 1980 (May, Oct.), 1981 (June, Oct.), 1982 (July, Aug) and 1983 (Feb, Sept.) (Table 1). Voucher specimens were deposited at the Univerisity Herbarium, Department of Botany, University of Peradeniya, Sri Lanka. The plant material was washed in fresh water, transferred into bottles (10 1.20 1.) and sufficient methanol added to completely cover the plant material. The bottles were transported to the laboratory.

\subsection{Extraction}

Methanol was decanted from the bottles which contained the plant material 1 to 4 weeks after collection and storage. The algal material was reduced in size by chopping and fresh methanol was introduced into the bottle to completely cover the plant material. The mixture was allowed to stand at room temperature for two days. This was repeated twice with fresh methanol. The plant material was then extracted successively with cold light petroleum $\left(40-60^{\circ} \mathrm{C}\right)$ and cold chloroform for 2 days, three times. With the algae collected in 1980 and 1981, dichloromethane was used as the solvent instead of chloroform, as a shortage of chloroform was experienced during this time. The methanol, petrol and chloroform/dichloromethane solubles were combined separately, and concentrated to dryness on a rotavapor at temperatures below $40^{\circ} \mathrm{C}$. A separate extraction of $C$. conoides was carried out with light petroleum $\left(40-60^{\circ} \mathrm{C}\right)$ under reflux conditions for two days and the petrol solubles were concentrated on a rotavapor at temperatures below $40^{\circ} \mathrm{C}$. The resulting solvent-free extractives were subjected to antimicrobial screening tests as described below.

\subsection{Cladosporium-TLC-Bioassay}

The foregoing solvent-free extracts $(2 \mathrm{mg}$ ) were spotted on TLC plates (silica gel $60 \mathrm{PG}_{254-366}, 0: 5 \mathrm{~mm} \times 20 \mathrm{~cm} \times 20 \mathrm{~cm}$ ) and the plates were developed in ethyl acetate: light petroleum (1:1). The plates, after air-drying overnight, were sprayed with a suspension of conidia of Cladosporium cladosporioides in Czapek-Dox nutrient solution and incubated in a moist chamber at $26 \pm$ $2^{0} \mathrm{C}$ for $48 \mathrm{~h}{ }^{11}$ The regions in which the growth was inhibited, appeared light coloured against a background of green mycelia. The diameter of the zones of inhibition was measured in $\mathrm{mm}$; the zones of inhibition were usually approximately circular. The extracts which showed inhibition are given in Table 1 with $R_{f}$ value (distance travelled by the spot/distance travelled by the solvent front) and the diameter of the zone of inhibition. Benlate $(0.2 \mathrm{mg}$ in $\mathrm{MeOH} ; 50 \%$ active ingredient methyl 1-(butylcarbonyl)2-benzimidazolecarbamate, Du Pont, USA) was spotted on each TLC plate as the standard and the diameter of the resultant inhibition area was measured. Some of the extracts were not tested for Cladosporium-TLC bioassay: (Table 1). 


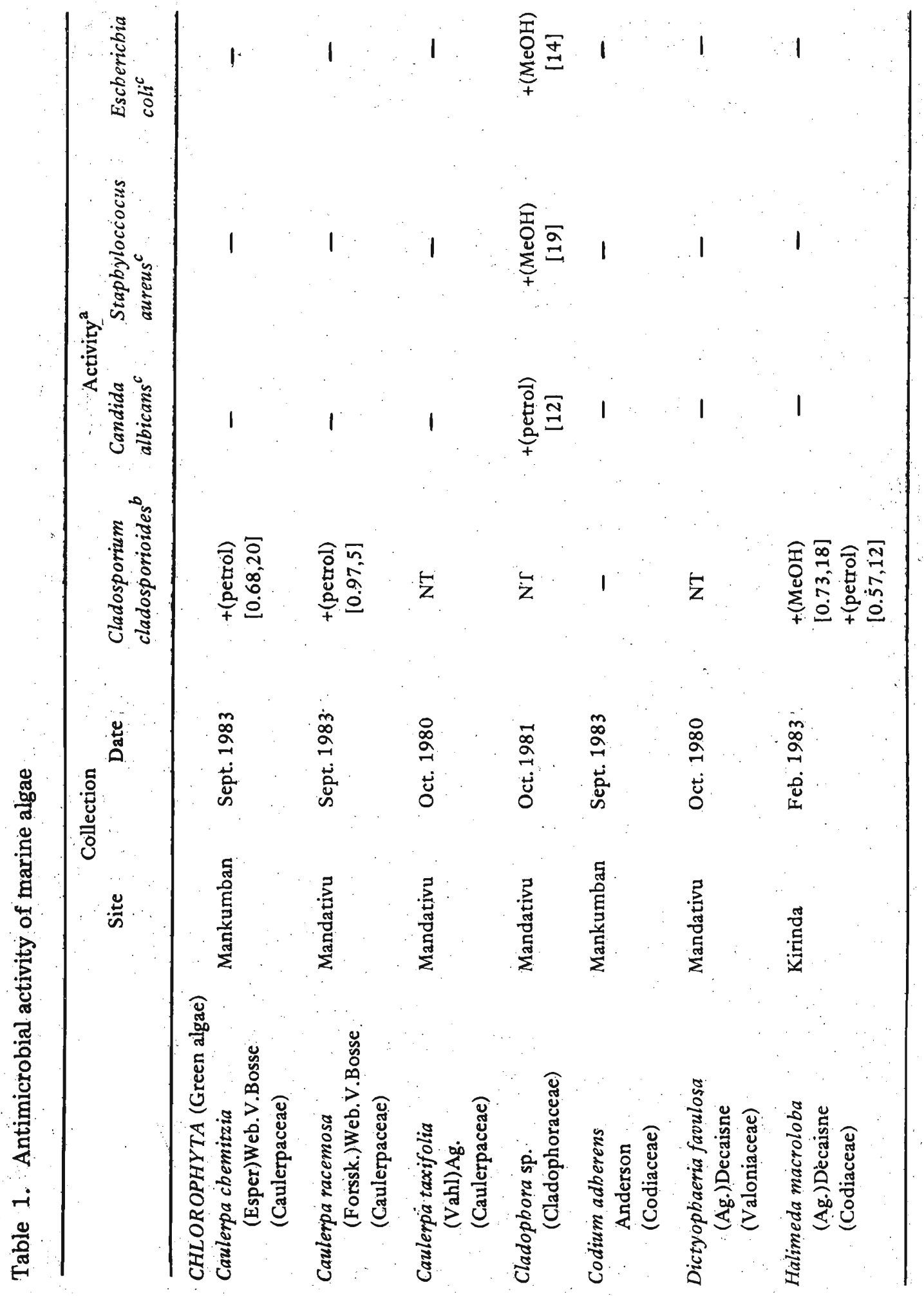




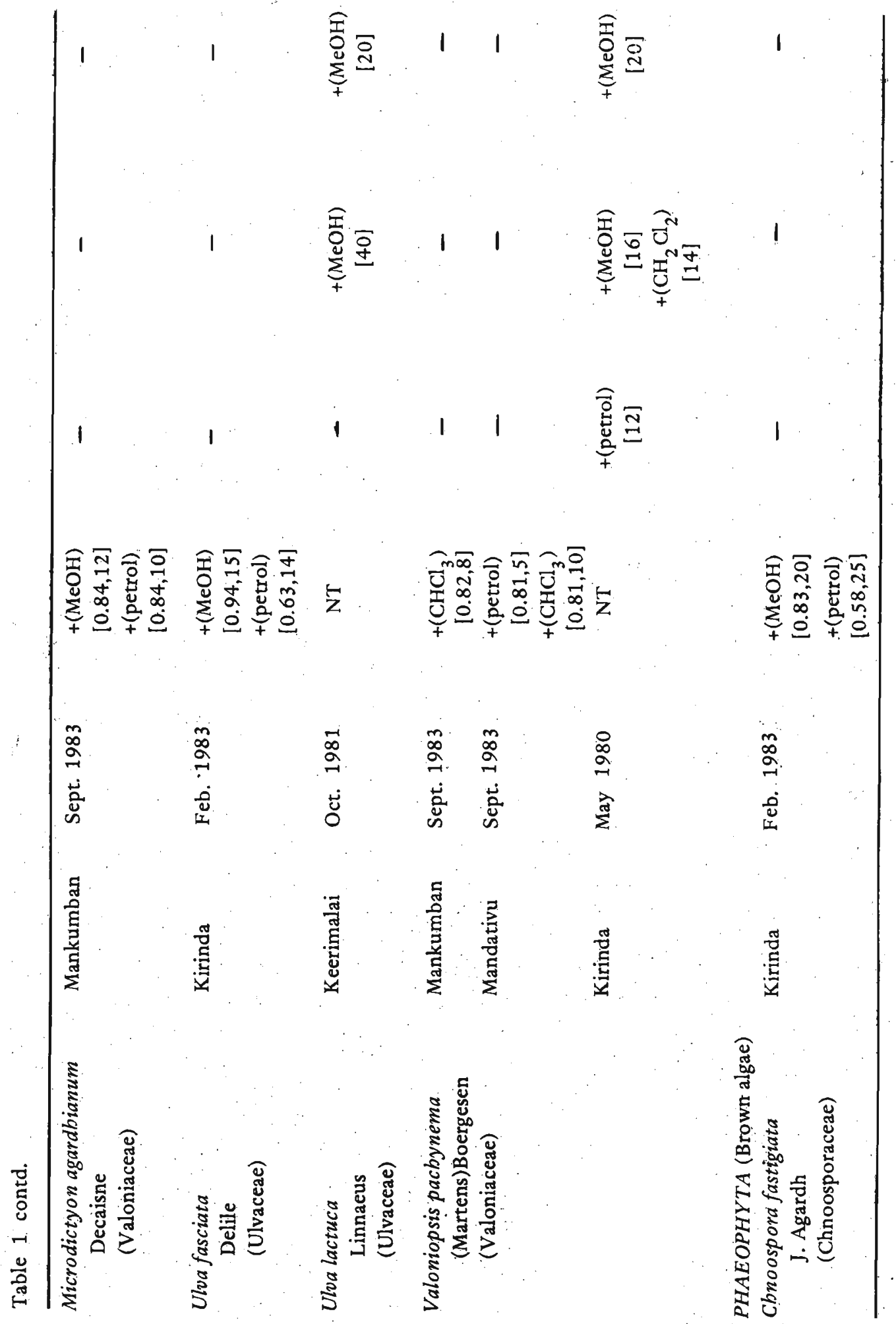




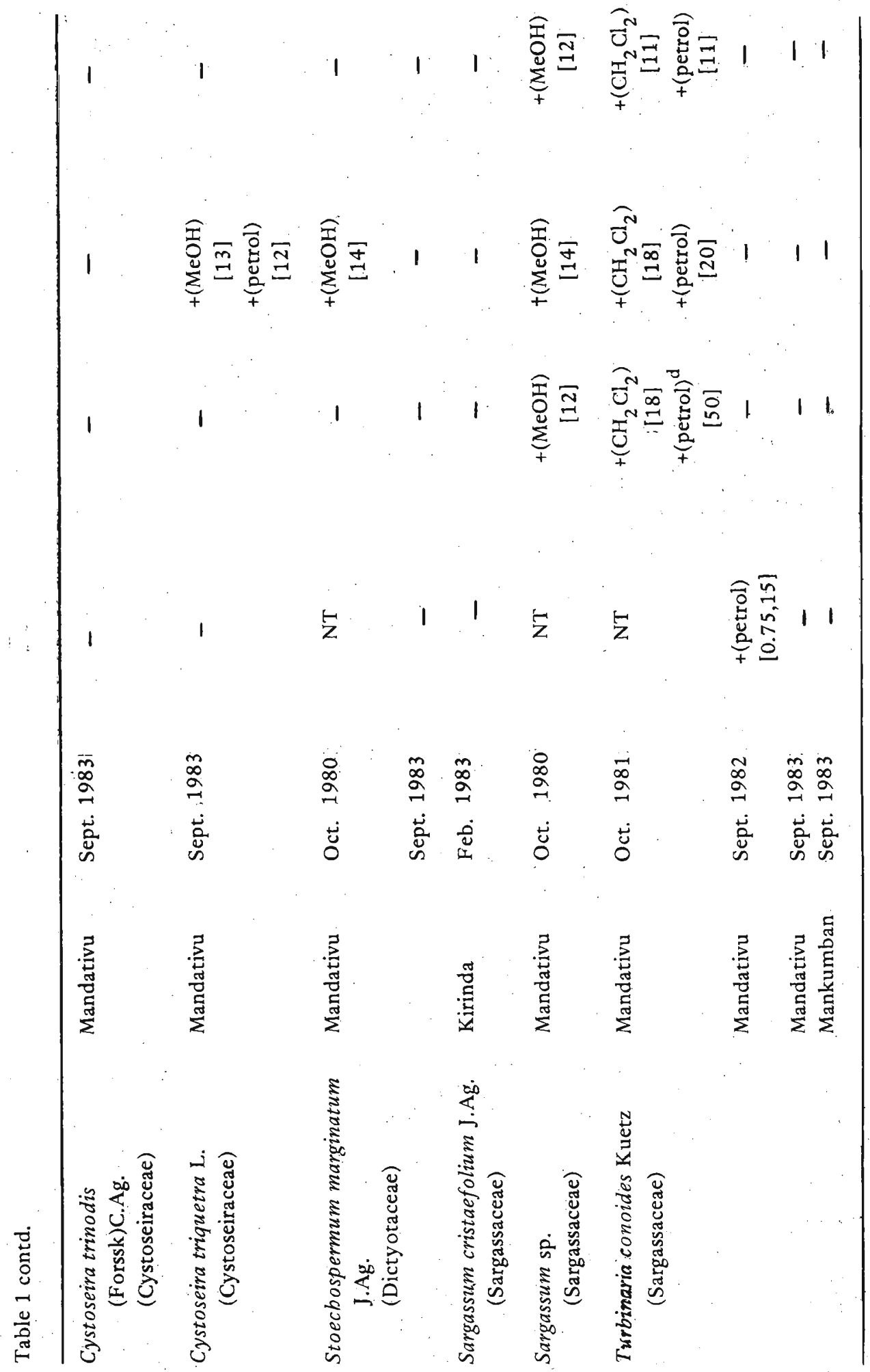




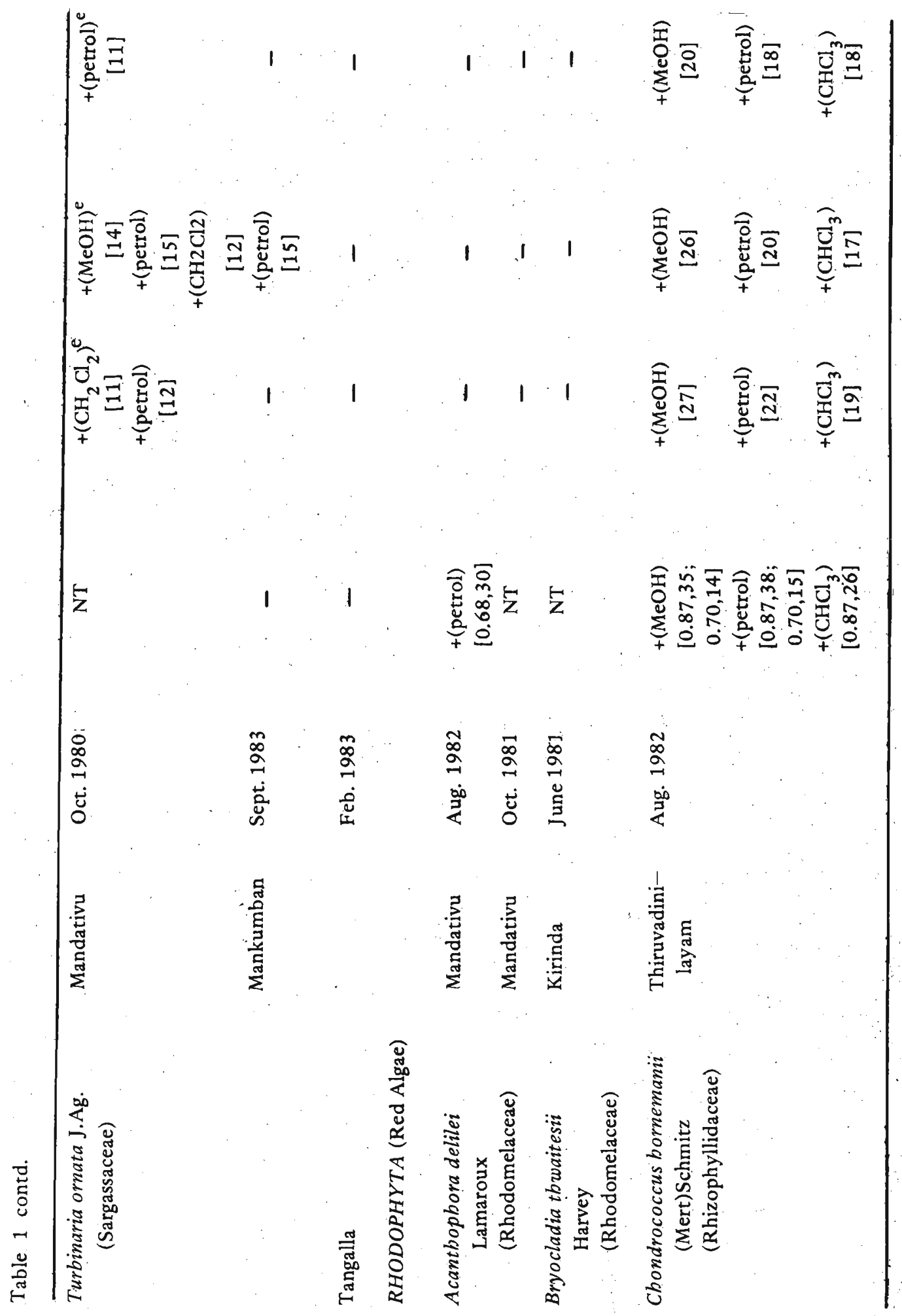




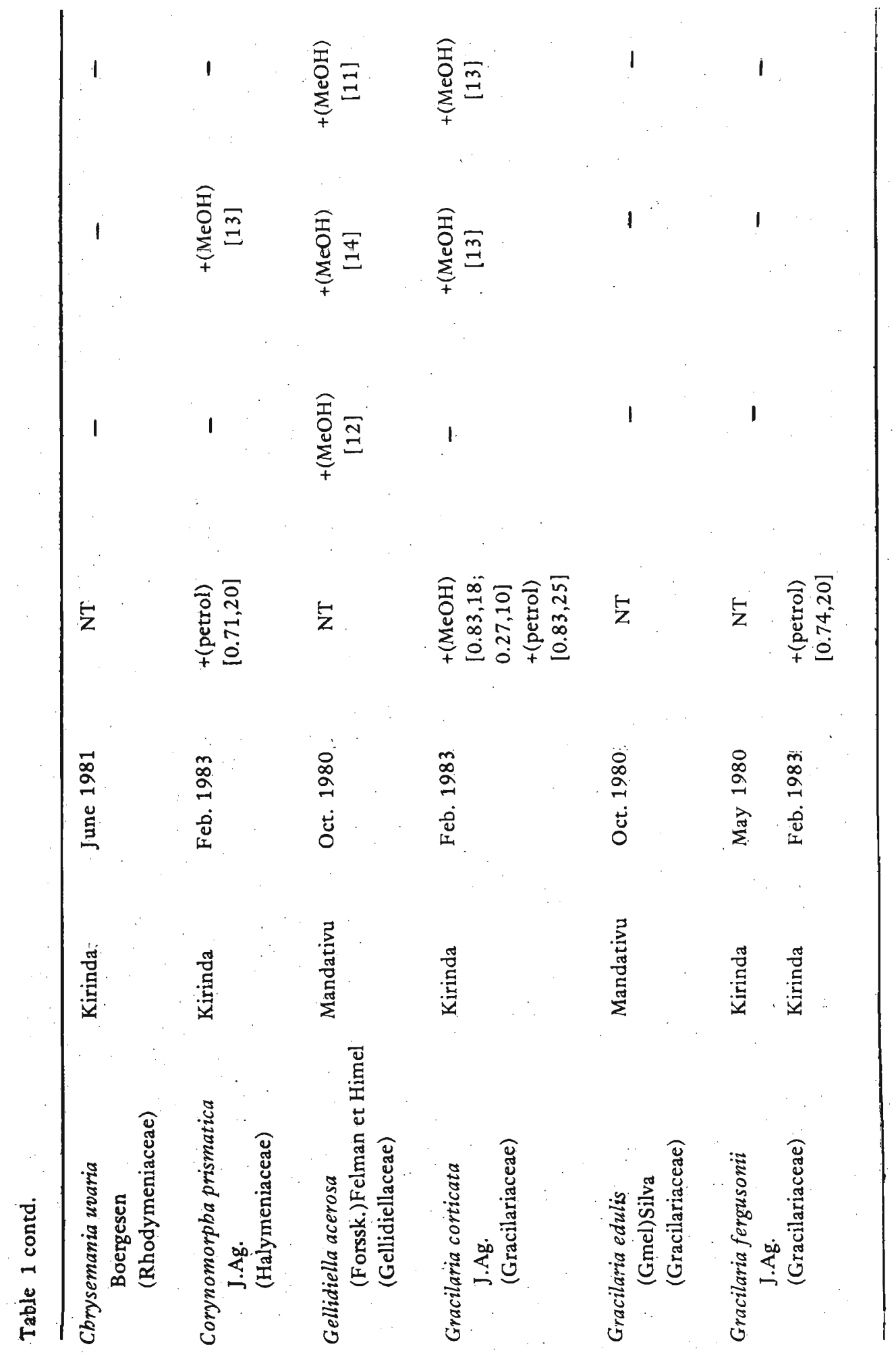




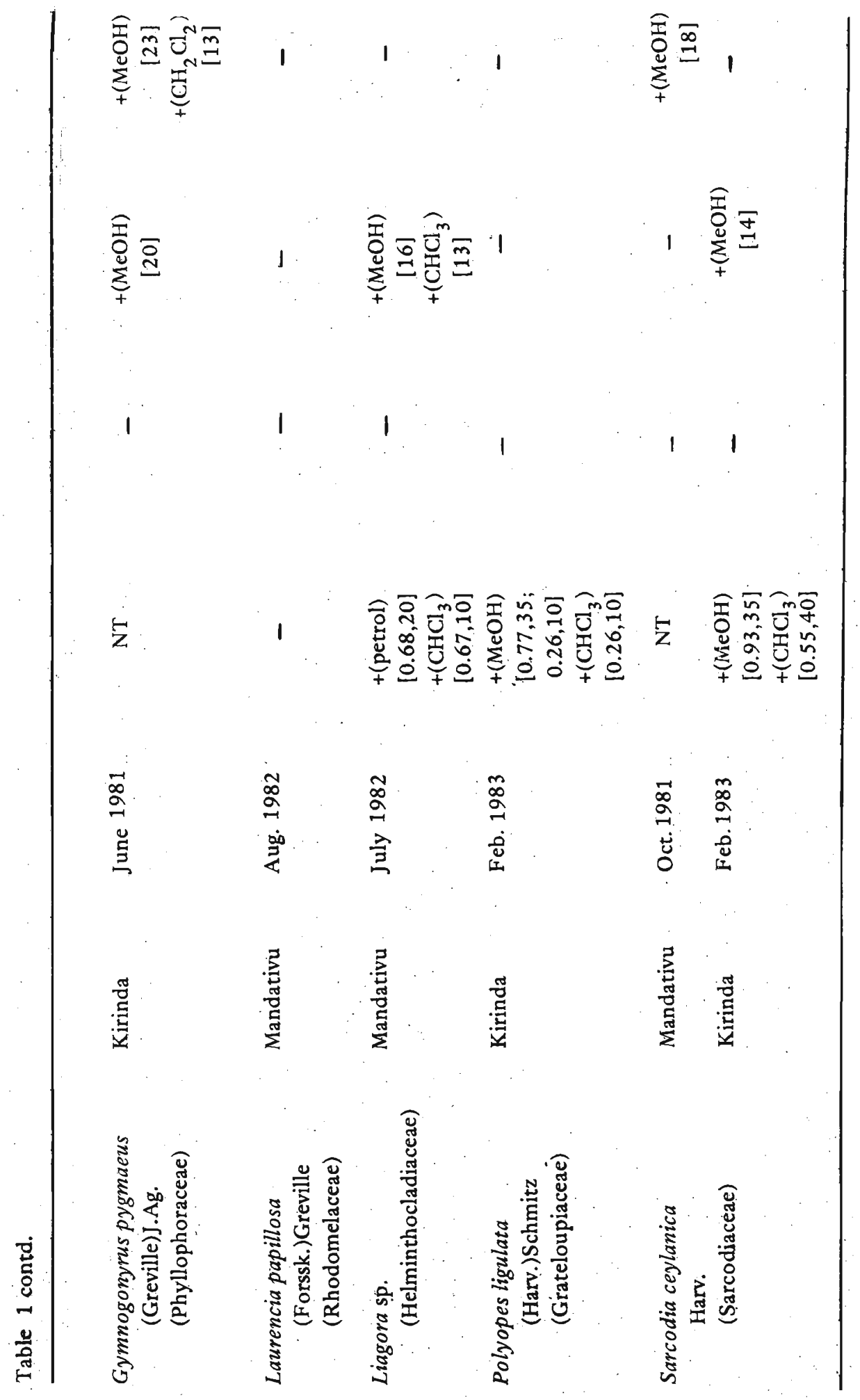




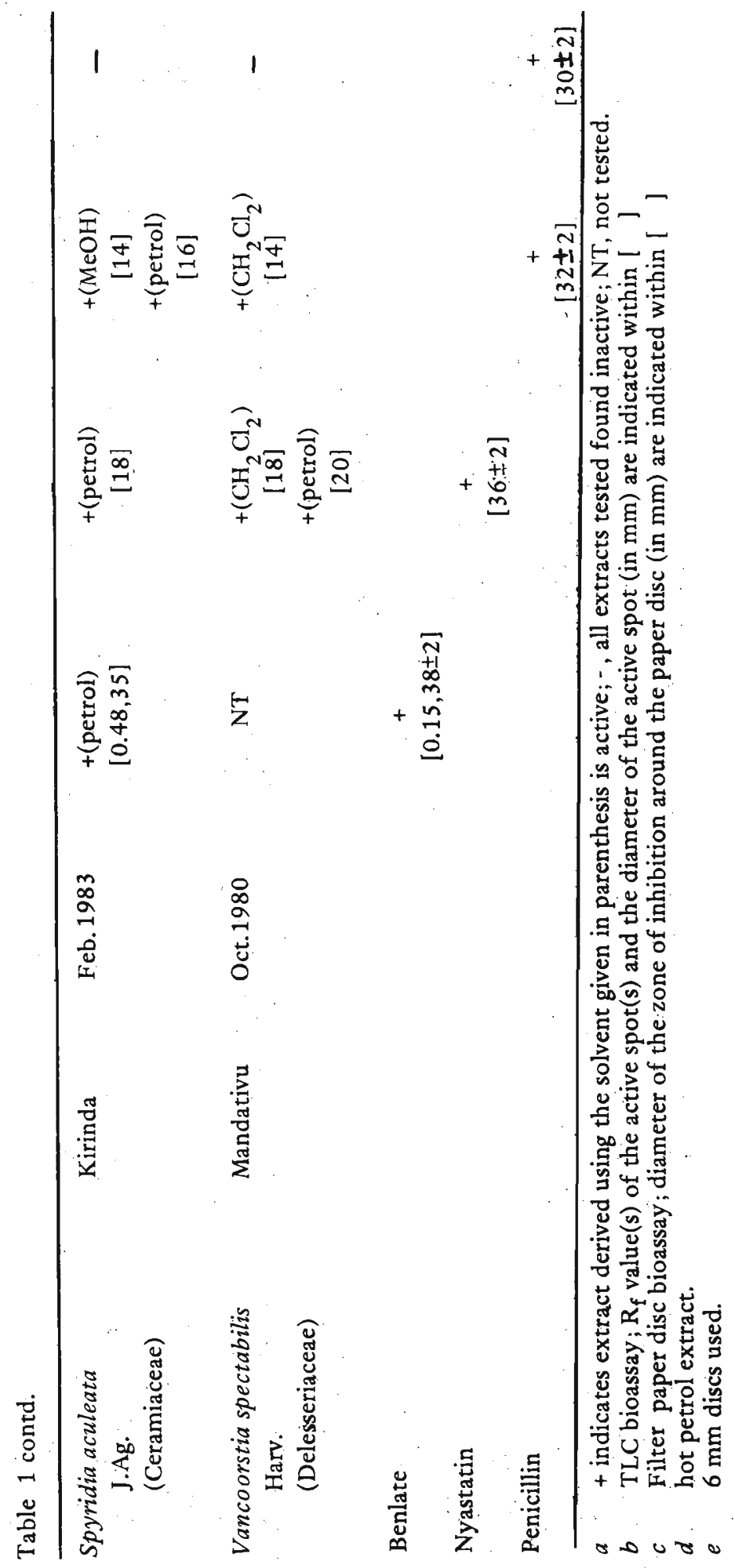




\subsection{Screening against Staphylococcus aureus, Escherichia coli and Candida albicans}

Aqueous ethanolic solutions $(1 \mathrm{ml})$ of the extracts $(15 \mathrm{mg})$ were absorbed into ten $6 \mathrm{~mm}$ paper discs. After ovendrying $\left(42^{\circ} \mathrm{C}\right)$ the discs were aseptically placed on Muller Hintant Agar (MHA) plates seeded with $S$. aureus (Oxford stain) and E. coli, and on Saboured Agar plates seeded with $C$. albicans. Tablets of Penicillin (10 i.u., DIFCO, Detroit, U.S.A.), standard for $E$. coli and $S$. aureus assay, and Nystatin $(25 \mu \mathrm{g}$, DIFCO, Detroit, U.S.A.), standard for C. albicans assay, were also placed on a separate set of seeded MHA and Saboured Agar plates, respectively. ${ }^{1}$ The plates were incubated at $38^{\circ} \pm 2^{\circ} \mathrm{C}$ for $48 \mathrm{~h}$ and the diameter of the Zone of inhibition on agar around the paper disc/tablet was measured. The results are given in Table 1 .

\subsection{Fractionation of the extractives of Chondrococcus hornemanni}

A large sample (dry wt. $1.5 \mathrm{~kg}$ ) of C. hornemanni was collected in Thiruvadinilayam and stored in chloroform:methanol $(1: 1)$ mixture for 2 weeks. The extract was filtered and the filtrate on standing separated into two layers and these were treated separately. The aqueous layer was washed with chloroform and the washings were combined with the organic layer. The combined organic layer was washed with water, dried over anhydrous $\mathrm{MgSO}_{4}$ and concentrated to obtain a brown oil $(14.1 \mathrm{~g}$ ). Flash chromatography (silica gel $\mathrm{GF}_{25}$ Merck, light petroleum and $\mathrm{CHCl}_{3}$ ) of the brown oil afforded a white crystalline solid $(57 \mathrm{mg})$, m.p. $52-55^{\circ} \mathrm{C},[\propto]_{\mathrm{D}} ;+18.7^{\circ}(c, 1.34$, $\mathrm{CHCl}_{3}$ ). IR $\vee \mathrm{KBa} \mathrm{cm}^{-1}: 2920,1620,1450,1100,900,700 .{ }^{1} \mathrm{H}-\mathrm{NMR}$ $\left(60 \mathrm{MHz} \mathrm{CCl}_{4}\right): \delta(\mathrm{ppm}) 5.82(\mathrm{IH}, \mathrm{D}, \mathrm{J}=3 \mathrm{HZ}), 5.62(\mathrm{IH}, \mathrm{d}, \mathrm{J}=3 \mathrm{~Hz}), 4.03$ $(\mathrm{IH}, \mathrm{d}, \mathrm{J}=10 \mathrm{~Hz}), 3.80(2 \mathrm{H}, \mathrm{s}), 2.9-1.9(4 \mathrm{H}, \mathrm{m}), 1.80(3 \mathrm{H}, \mathrm{s}), 1.68(3 \mathrm{H}, \mathrm{s}) . \mathrm{MS}$ : $\mathrm{m} / \mathrm{z}$ (relative intensity) $366\left(\mathrm{M}^{+}-\mathrm{Cl}, 6 \%\right), 285(26), 249(16), 205(18), 203$ $(22), 169(15), 167(29), 127(32), 125(34), 113(19), 105(20), 103(26)$, $91(30), 79(36), 77(100)$. Further elution of the column gave a colourless oil $\left(766 \mathrm{mg}\right.$ ) which was homogeneous on TLC. IR $v$ neat $\mathrm{cm}^{-1}: 2920,1440$, $1250,1200,675 .{ }^{1} \mathrm{H}-\mathrm{NMR}\left(\mathrm{CCl}_{4}\right): \delta(\mathrm{ppm}) 5.83-5.50(\mathrm{~m}), 5.10(\mathrm{~s}, \mathrm{br}), 4.90$ $(\mathrm{s}, \mathrm{br}), 4,17(\mathrm{~s}), 4.1,0(\mathrm{~s}), 4.04(\mathrm{~s}), 3.97(\mathrm{~s}), 3.91(\mathrm{~s}), 2.30(\mathrm{~s}), 2.25(\mathrm{~s}), 1.83(\mathrm{~s})$, 1.80 (s). MS: $m / z 252,250,248,209,207,205,191,171,169,133,129$; $127,103,102,79,75,69,68,67,65$.

\section{Results and Discussion}

Cold methanol, petroleum and chloroform/dichloromethane extracts of 35 algae belonging to Chlorophyta (11 species), Phaeophyta ( 8 species) and Rhodophyta (16 species) were examined for antimicrobial activity. against $C$. cladosporioides, C. albicans, S. aureus and E. coli. The results (Table 1) show that 26 species exhibited activity against one or more microorganisms. 


\subsection{Chemical fractionation of the extractives of Chondrococcus horne- manni}

The extracts of $C$. hornemanni inhibited the growth of all four microbes tested, and the observed activities were comparable to those of a standard antibiotic Penicillin and standard fungicides, 'Benlate' and 'Nystatin'. The active extract of $C$. hornemanni was partitioned on a silica gel column using combinations of light petroleum and $\mathrm{CHCl}_{3}$ with increasing polarity. A white crystalline solid (1) and a colourless oil (2) were obtained. The IR spectrum of the solid showed a band at $1620 \mathrm{~cm}^{-1}$ corresponding to an olefinic double bond. The ${ }^{1} \mathrm{H}-\mathrm{N}$ MR spectrum of this compound indicated the presence of two tertiary methyl groups $(\delta .1 .80$ and 1.68), three hydrogens on halogen bearing carbon atoms $(\delta 4.03, \mathrm{IH}, \mathrm{d}, \mathrm{J}=10 \mathrm{~Hz}$ and $\delta 3.80,2 \mathrm{H}, \mathrm{s})$ and two olefinic hydrogens which are geminally coupled ( $\delta 5.83,1 \mathrm{H}, \mathrm{d}$, and $\mathrm{J}=3 \mathrm{~Hz}$ and $\delta \quad 5.62, \mathrm{IH}, \mathrm{d}, \mathrm{J}=3 \mathrm{HZ}$ ). The mass spectrum showed two peaks at $\mathrm{m} / z 366$ and 285 corresponding to $\mathrm{M}-\mathrm{Cl}$ and $\mathrm{M}-\mathrm{Cl}-\mathrm{HBr}$, respectively. High resolution mass spectral data indicated the molecular formula of the ion at $m / z 285$ to be $\mathrm{C}_{10} \mathrm{H}_{14} \mathrm{Cl}_{2} \mathrm{Br}$. This suggested that compound 1 . was identical to 6-bromo-3-bromomethyl -2,3,7-trichloro7-methyl-1-octene previously isolated from C. hornemanni. ${ }^{3}$. This compound was found to be inactive against $C$. cladosporioides.

The colourless oil (2) obtained from the above column, was homogeneous on TLC although GLC and HPLC analysis suggested the presence of more than one compound in the oil. The oil was not fractionated into more than one component by either silica gel $/ \mathrm{AgNO}_{3}$ impregnated silica gel chromatography (plates or column) eluted with $n$-hexane or HPLC (Whatman Partisil-10 ODS 2, aqueous $\mathrm{MeOH}$ ). The oil (2) corresponded to the inhibition zone at $R_{f} 0.87$ in the Cladosporium-TLC-bioassay. Mass spectral fragments at $m / z 252,250,248\left(\mathrm{M}^{+}\right), 209,207,205(\mathrm{M}-43), 171$, $169(\mathrm{M}-\mathrm{Br}), 133(\mathrm{M}-\mathrm{Br}-\mathrm{Cl}-\mathrm{H}), 129,127(\mathrm{M}-\mathrm{Br}-43+\mathrm{H})$ and 69 (base peak) suggested that the active fraction contained mainly dihalogenated monoterpenes. ${ }^{10}$ The presence of several halogenated monoterpenes in C. hornemanni has been reported previously. ${ }^{3,10,15}$ Structurally related compounds isolated from Delisea fimbriata (Rhodophyta) have also displayed antimicrobial activity. 12,13

\subsection{Screening for antimicrobial activity}

The extracts of Cladosphora sp, Valoniopsis pachynema, Turbinaria conoides, Corynomorpha prismatica, Gracilaria corticata, Liagora sp., Sarcodia ceylanica and Spyridia aculeata also showed antibacterial and antifungal activity but to a lesser extent than $C$. hornemanni. The methanol extract of $G$. corticata produced two inhibition areas in the Cladosporium-TLC-bioassay plate (petrol:EtOAc:1:1) corresponding to low polar $\left(\mathrm{R}_{\mathrm{f}} 0.83\right)$ and high polar $\left(R_{f} 0.27\right)$ active constituents. The $R_{f}$ value of the inhibition area produced by the high polar compound was identical to that of acrylic acid. 
It is noteworthy that the antimicrobial principle of $G$. folifera and G. varrucosa has been reported to be acrylic acid.?

The extracts of Caulerpa chemitzia, Caulerpa racemosa, Halimeda macroloba, Ulva fasciata, Microdictyon agardharanum, Chnoospora fastigiata, Acanthopora delilei, Gracilaria fergusonii and Polyopes ligulata inhibited only $C$. cladosporioides. In a previous survey on fungistatic properties of marine algae, ${ }^{14}$ C. racemosa . was, however, found to be particularly active against Candida albicans and Cryptococcus neoformans.

Only antibacterial properties were detected in the extracts of Ulva lactuca, Cystoseira triquetra, Stoechospermum marginatum, Turbinaria ornata, Cymnogyrus pygmaeus and Sarcodia ceylanica. Our results of $U$. lactuca are in agreement with those of a previous study, ${ }^{2}$ and the active compound is probably (TLC) acrylic acid. ${ }^{8}$ The antibacterial constituents of S. marginatum has been identified as a spatol acetate.

The extracts of Caulerpa taxifolia, Codium adherens, Dictyosphaeria favulosa, Cystophyllum muricatum, Sargassum cristaefolium, Bryocladia ihwaitesii, Chrysemania uvaria, Gracilaria edulis and Laurencia papillosa did not inhibit the growth of the microbes tested. A homogenized preparation of $L$. papillosa has, however, been found to be a potent inhibitor of some pathogenic fungi in a previous survey. ${ }^{14}$

Varying activities of the extracts were observed with different collections of algal specimens, e.g. $V$. pachynema, S. marginatum, $T$. conoides, $T$. ornata and S. ceylanica. This may be attributed partly to seasonal variations ${ }^{2}$ and ecotypic variations from different locations. ${ }^{4}$

\section{Acknowledgements}

We thank Professor S.N. Arseculeratne formerly of the Dept. of Microbiology, University of Peradeniya, for permitting the use of facilities for bacteriological testing, Dr. S.S.M. de Silva and Mr. S.K.T. Gamage for some preliminary testing and Mrs. S.C. Weerasekera for technical assistance. We gratefully acknowledged financial assistance from the Natural Resources, Energy and Science Authority of Sri Lanka.

\section{References}

1. BARRY, A.L. \& THORNSBERRY, C. (1980) Manual of Clinical Microbiology, 3rd ed., $463-$ 474 pp.;. American Society for Microbiology.

2. BIARD, J.F., VERBIST, J.F., LE BOTERIFF, J., RAGAS, G. \& LECOCQ M. (1.980) Planta Medica, Supplement, 136-151.

3. BURRESON, B.J., WOOLARD, F.X. \& MOORE, R.E. (1975) Chem. Lett., 1111-1114.

4. BURRESON, B.J. WOOLARD, F.X. \& MOORE, R.E. (1975) Tetrabedron Lett., 2155-2158. 
5. DE SILVA, S.S.M., GAMAGE, S.K.T., KUMAR, N.S. \& BALASUBRAMANIAM, S. (1982) Pbytocbemistry, 21: 944-945.

6. DIAZ-PIFERRER, M. (1979) In Marine Algae in Pharmaceutical Science (Hoppe, H.A., Levring, T., Tanaka, Y. ed.) 149-164 Pp.

7. DURAIRATNAM, M. (1961) Bulletin No.10, 1-181 pp. Fisheries Research Station, Ceylon.

8. GLOMBITZA, K. -W. \& HEYȘER, R. (1971) Helgolander wiss. Meeresunters 22 : $442-453$.

9. GLOMBITZA, K. -W. (1979) In Marine Algae in Pharmaceutical Science (Hoppe, H.A., Levring, T., Tanaka, Y. ed.), 303-342 pp., Walter de Gruyter, Berlin.

10. ICHIKAWA, N., NAYA, Y. \& ENOMOTO, S. (1974) Chem. Lett, 1333-1336.

11. KLARMAN, W.L. \& STANFORD, J.B. (1968) Life Science 7 : 1095-1105.

12. PETTUS, J. A., WING, R.M. \& SIMS, J.J. (1977) Tetrabedron Lett., 41-44.

13. ROSE, A.F., PETTUS, J.A. \& SIMS, J.J. (1977) Tetrabedron Lett., 1847-1850.

14. WELCH, A.M. (1961) J. Bacteriol. 83 : 97-99.

15. WOOLARD, F.X., MOORE, R.E., MAHENDRAN, M. \& SIVAPALAN, A. (1976) Pbyto-' chemistry, 19 : 1069-1070. 